\title{
Lactobacillus satsumensis sp. nov., isolated from mashes of shochu, a traditional Japanese distilled spirit made from fermented rice and other starchy materials
}

\author{
Akihito Endo and Sanae Okada \\ Department of Brewing, Tokyo University of Agriculture, Tokyo 156-8502, Japan
}

Correspondence

Akihito Endo

60020001@nodai.ac.jp

\begin{abstract}
Gram-positive, rod-shaped, motile lactic acid bacteria (strains NRIC 0603, NRIC 0604 ${ }^{\top}$, NRIC 0605 and NRIC 0606) were isolated from shochu mashes using an enrichment culture approach. These strains clustered in the Lactobacillus casei-Pediococcus group and were closely related to Lactobacillus nagelii and Lactobacillus mali on the basis of 16S rRNA gene sequence similarity. Levels of DNA-DNA relatedness revealed genotypic separation of the four isolates from the above two species. The isolates are therefore considered to represent a novel species, for which the name Lactobacillus satsumensis is proposed. The type strain is NRIC $0604^{\top}\left(=\right.$ JCM $12392^{\top}=$ DSM $\left.16230^{\top}\right)$.
\end{abstract}

During a study of lactic acid bacteria originating from plant material, 62 strains were isolated from mashes of shochu, a traditional Japanese distilled spirit made from fermented rice, sweet potato, barley and other starchy materials, together with Saccharomyces cerevisiae and Aspergillus niger. Fermented mashes contain 15-18\% alcohol and they are kept at acidic $\mathrm{pH}(3 \cdot 0-4 \cdot 0)$ as a result of the production of citric acid by the mould during fermentation. The mash is therefore a harsh environment for lactic acid bacteria. After $16 \mathrm{~S}$ rRNA gene sequence analysis of all the isolates, four strains (NRIC 0603, NRIC $0604^{\mathrm{T}}$, NRIC 0605 and NRIC 0606) underwent subsequent study because they clustered separately from recognized species of lactic acid bacteria. Levels of DNA-DNA relatedness also separated the strains from related species. This paper details the taxonomic study of the four strains and their proposed classification in a novel species, Lactobacillus satsumensis sp. nov.

The enrichment culture approach was employed for isolation of lactic acid bacteria from fermented mashes of shochu made from sweet potato that were collected at a shochu distillery in the South Kyushu district of Japan. The enrichment medium comprised $1.0 \%$ D-glucose, $1.0 \%$ yeast extract, $0 \cdot 5 \%$ polypeptone, $0 \cdot 2 \%$ sodium citrate, 10 p.p.m. sodium azide and 10 p.p.m. cycloheximide, and was adjusted to $\mathrm{pH} 5.0$ with $\mathrm{HCl}$. Fermented mashes were inoculated in the above medium and incubated at $30^{\circ} \mathrm{C}$. After incubation for 3 or 4 days at $30^{\circ} \mathrm{C}$, the cultured broth

Published online ahead of print on 24 September 2004 as DOI 10.1099/ijs.0.63248-0.

The GenBank/EMBL/DDBJ accession number for the 16S rRNA gene sequence of strain NRIC $0604^{\top}$ is $\mathrm{AB} 154519$. was plated on MRS (Oxoid) agar containing 10 p.p.m. sodium azide and 10 p.p.m. cycloheximide and was then incubated. Colonies were picked on MRS agar and maintained on MRS agar containing $0.5 \% \mathrm{CaCO}_{3}$.

Chromosomal DNA was prepared from bacterial strains by the method of Zhu et al. (1993) and was then used as a template for 16S rRNA gene sequence amplification. Large fragments of the 16S rRNA gene sequence were amplified by PCR using two primers: 8F (5'-AGAGTTTGATCMTGGCTCAG-3', positions 8-27) and 15R (5'-AAGGAGGTGATCCARCCGCA-3', positions 1541-1522); position numbers were based on the Escherichia coli numbering system (GenBank accession no. V00348; Brosius et al., 1981). The PCR products were purified using a QIAquick PCR purification kit (Qiagen) according to the manufacturer's instructions. They were sequenced using a BigDye Terminator cycle sequencing kit (Applied Biosystems) and an automatic DNA sequencer (model 310; Applied Biosystems). The following seven primers were used: $8 \mathrm{~F}$, 930F (5' -GCACAAGCGGTGGAGCATGTGG-3' , positions 933-954), 1400F (5'-TGTACACACCGCCCGT-3' , positions 1391-1406), 520R (5'-ACCGCGGCTGCTGGC-3', positions 531-517), 800R (5'-CAGGACTACCAGGGTATCTAAT-3', positions 804-787), 1100R (5'-AGGGTTGCGCTCGTTG-3', positions 1115-1100) and 15R. The closest recognized relatives of the isolates were determined by performing database searches, and sequences of closely related species were retrieved from GenBank. Multiple alignments of the sequences were carried out with the program CLUSTAL X (version 1.18) (Thompson et al., 1997). Distance matrices for the aligned sequences were calculated using the two-parameter method of Kimura (1980). 
The neighbour-joining method was used to construct a phylogenetic tree (Saitou \& Nei, 1987). The robustness of individual branches was estimated by bootstrapping with 1000 replicates (Felsenstein, 1985). The 16S rRNA gene sequence (positions 8-1541) was determined for NRIC $0604^{\mathrm{T}}$, and this was used to search for sequence similarity using DataBase. The highest sequence similarity to NRIC $0604^{\mathrm{T}}$ was found with Lactobacillus nagelii, Lactobacillus mali, Lactobacillus murinus and Pediococcus damnosus, the values being $95 \cdot 3,95 \cdot 0,94 \cdot 7$ and $94 \cdot 8 \%$, respectively; these species belong to the Lactobacillus casei-Pediococcus group (Fig. 1). Partial sequences (positions 8-531) of the $16 \mathrm{~S}$ rRNA gene were determined for strains NRIC 0603, NRIC 0605 and NRIC 0606; these partial sequences were identical to one another and to that of NRIC $0604^{\mathrm{T}}$ (positions 8-531). Therefore, we concluded that the four isolates belong to the same taxon and that this is located in the Lactobacillus casei-Pediococcus group.

Extraction and isolation of bacterial DNA were performed by the method of Marmur (1961) as modified by Ezaki et al. (1983). DNA-DNA hybridization was carried out by the microdilution well technique using photobiotin for labelling of DNA (Ezaki et al., 1989). DNA base compositions ( $\mathrm{G}+\mathrm{C}$ content) of strains tested were determined by HPLC as described by Tamaoka \& Komagata (1984). Strains NRIC 0603 , NRIC $0604^{\mathrm{T}}$, NRIC 0605 and NRIC 0606 showed high levels of DNA-DNA relatedness $(96-99 \%)$ to one another. By contrast, NRIC $0604^{\mathrm{T}}$ showed low levels of DNA-DNA relatedness to the type strains of $L$. nagelii (6\%) and L. mali (7\%). The DNA G+C content of the four isolates ranged from 39 to $41 \mathrm{~mol} \%$.

Cell shape, cell size and Gram staining (Hucker \& Conn,

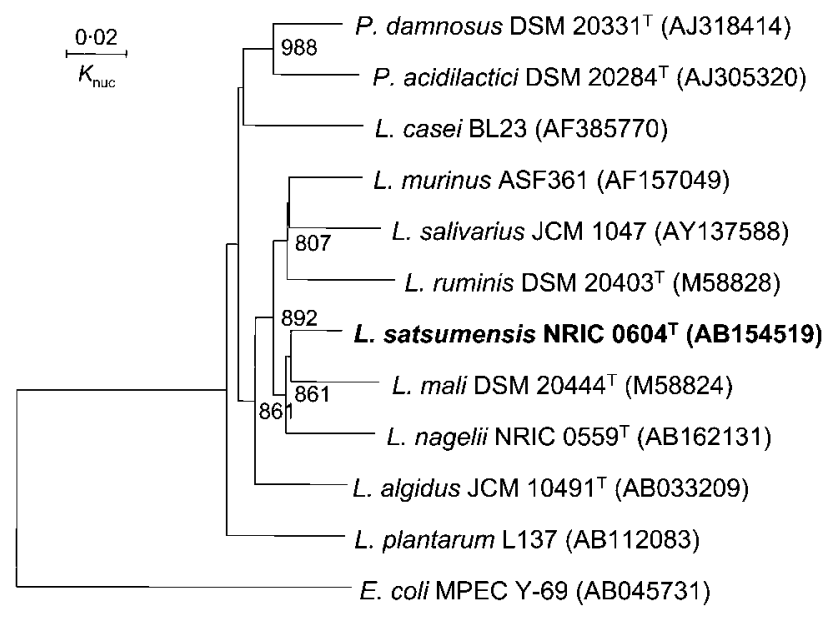

Fig. 1. Phylogenetic relationships of isolates in the Lactobacillus casei-Pediococcus group based on 16S rRNA gene sequences. The tree was constructed by the neighbour-joining method, and approximately $1440 \mathrm{nt}$ were used for comparison. Escherichia coli was used as an outgroup.
1923) were determined on cultures grown in MRS broth at $30^{\circ} \mathrm{C}$ for $24 \mathrm{~h}$. Motility was tested in MRS soft agar and flagella were stained by the method of Toda (1928). Catalase activity was determined on cells grown on MRS agar. Gas production from glucose was determined using a Durham tube in MRS broth. Nitrate reduction, acid formation from carbohydrates and production of dextran from sucrose were determined by the methods described by Tanasupawat et al. (1998). The effects of temperature and various initial $\mathrm{pH}$ levels were tested in MRS broth. Resistance to $\mathrm{NaCl}$ and ethanol was examined in MRS broth containing $5 \%$ $(\mathrm{w} / \mathrm{v}) \mathrm{NaCl}$ or $10 \%(\mathrm{v} / \mathrm{v})$ ethanol after incubation for 5 days at $30^{\circ} \mathrm{C}$. Type of fermentation was determined enzymically using the F-kit ethanol (Roche Diagnostics) as described by Okada et al. (1991). The isomer type of lactic acid was analysed by HPLC as described by Manome et al. (1998). Preparation of cell walls and determination of peptidoglycans were carried out by the methods described by Komagata \& Suzuki (1987), except that TLC was performed on cellulose sheets. Various phenotypic characteristics of the isolates were similar to those of L. nagelii (Edwards et al., 2000) and L. mali (Carr \& Davies, 1970; Nonomura, 1983; Kaneuchi et al., 1988), which are the phylogenetically closest related species (Table 1). In addition to the strains tested, L. nagelii and L. mali are motile, have meso-diaminopimelic acid in the cell wall and produce dextran from sucrose. These characteristics are unique in the genus Lactobacillus. The strains investigated cannot be distinguished from $L$. nagelii and L. mali based on their phenotypic characteristics, and levels of DNA-DNA relatedness were therefore used to provide accurate classification.

Based on the data provided, the four isolates are genetically distinguishable from recognized species of lactic acid bacteria, and thus represent a novel species, for which the name Lactobacillus satsumensis sp. nov. is proposed.

Table 1. Characteristics of Lactobacillus satsumensis sp. nov. and genetically closely related lactobacilli

Data for reference species are from Kaneuchi et al. (1988) (L. mali) and Edwards et al. (2000) (L. nagelii); motility and the presence of meso-diaminopimelic acid in the cell wall of $L$. nagelii NRIC $0559^{\mathrm{T}}$ were determined in the present study. +, Positive; -, negative; V, variable. All three species are motile, produce acid from D-fructose, D-trehalose and D-salicin and have mesodiaminopimelic acid in the cell wall. All three species are negative for acid production from D-ribose, D-xylose and lactose.

\begin{tabular}{|lccc|}
\hline Characteristic & $\begin{array}{c}\text { L. satsumensis } \\
\text { sp. nov. }\end{array}$ & L. mali & L. nagelii \\
\hline Catalase production & - & $\mathrm{V}$ & - \\
Acid from D-cellobiose & - & $\mathrm{V}$ & + \\
Growth in MRS broth & + & $\mathrm{V}$ & + \\
containing $5 \% \mathrm{NaCl}$ & & & \\
\hline
\end{tabular}




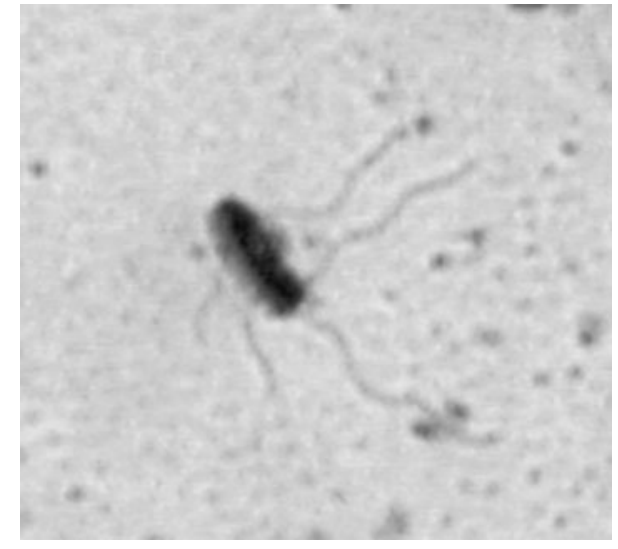

Fig. 2. Peritrichous flagella of Lactobacillus satsumensis $\mathrm{sp}$. nov. NRIC $0604^{\top}$ grown on an MRS slant at $30^{\circ} \mathrm{C}$ for $16 \mathrm{~h}$.

\section{Description of Lactobacillus satsumensis sp. nov.}

Lactobacillus satsumensis [sat.su.men'sis. N.L. masc. adj. satsumensis pertaining to Satsuma (old name for the southern part of Kyushu in Japan), from where the type strain was isolated].

Cells are Gram-positive rods measuring $0 \cdot 6-0 \cdot 8 \times 1 \cdot 0$ $1.5 \mu \mathrm{m}$. Cells occur singly or in pairs, and are motile with peritrichous flagella (Fig. 2). They are facultatively anaerobic and catalase-negative. Colonies on MRS agar are white, smooth and approximately $2 \mathrm{~mm}$ in diameter after incubation for 2 days. They are homofermentative and produce L-lactic acid as a main end-product from Dglucose. Nitrate is not reduced. Acid is produced from D-fructose, D-mannose, sucrose, D-salicin, D-trehalose and D-mannitol, but not from L-arabinose, D-ribose, D-xylose, D-cellobiose, lactose, melibiose, D-raffinose or starch. Some strains produce acid from D-gluconate, D-galactose and D-melezitose. Dextran is formed from sucrose. Cells grow at 15 and $45^{\circ} \mathrm{C}$ but not at 4 or $50^{\circ} \mathrm{C}$. Growth is observed in MRS broth containing $5 \%(\mathrm{w} / \mathrm{v})$ $\mathrm{NaCl}$ and at $\mathrm{pH} 3.5$ in MRS broth. No growth is observed in MRS broth containing $10 \%(\mathrm{v} / \mathrm{v})$ ethanol. Cells contain meso-diaminopimelic acid in their peptidoglycan. The DNA G + C content ranges from 39 to $41 \mathrm{~mol} \%$ (type strain $40 \mathrm{~mol} \%$ ).

The type strain is NRIC $0604^{\mathrm{T}}\left(=\mathrm{JCM} 12392^{\mathrm{T}}=\mathrm{DSM}\right.$ $\left.16230^{\mathrm{T}}\right)$. All strains were isolated from shochu mashes collected at a shochu distillery in the South Kyushu district of Japan.

\section{Acknowledgements}

We are grateful to the owner of the Kirishima Distillery Ltd, Miyazaki, Japan, for providing the fermentation samples and to Y. Takase, H. Okuno, K. Iwai and T. Uchiyama for their help and valuable discussion.

\section{References}

Brosius, J., Dull, T. J., Sleeter, D. D. \& Noller, H. F. (1981). Gene organization and primary structure of a ribosomal RNA operon from Escherichia coli. J Mol Biol 148, 107-127.

Carr, J. G. \& Davies, A. (1970). Homofermentative lactobacilli of cider including Lactobacillus mali nov. spec. J Appl Bacteriol 33, 768-774.

Edwards, C. G., Collins, M. D., Lawson, P. A. \& Rodriguez, A. V. (2000). Lactobacillus nagelii sp. nov., an organism isolated from a partially fermented wine. Int J Syst Evol Microbiol 50, 699-702.

Ezaki, T., Yamamoto, N., Ninomiya, K., Suzuki, S. \& Yabuuchi, E. (1983). Transfer of Peptococcus indolicus, Peptococcus asaccharolyticus, Peptococcus prevotii, and Peptococcus magnus to the genus Peptostreptococcus and proposal of Peptostreptococcus tetradius sp. nov. Int $J$ Syst Bacteriol 33, 683-698.

Ezaki, T., Hashimoto, Y. \& Yabuuchi, E. (1989). Fluorometric deoxyribonucleic acid-deoxyribonucleic acid hybridization in microdilution wells as an alternative to membrane filter hybridization in which radioisotopes are used to determine genetic relatedness among bacterial strains. Int J Syst Bacteriol 39, 224-229.

Felsenstein, J. (1985). Confidence limits on phylogenies: an approach using the bootstrap. Evolution 39, 783-791.

Hucker, G. J. \& Conn, H. J. (1923). Method of Gram Staining. New York State Agricultural Experiment Station Technical Bulletin no. 93. Ithaca, NY: New York State Agricultural Experiment Station.

Kaneuchi, C., Seki, M. \& Komagata, K. (1988). Taxonomic study of Lactobacillus mali Carr and Davis 1970 and related strains: validation of Lactobacillus mali Carr and Davis 1970 over Lactobacillus yamanashiensis Nonomura 1983. Int J Syst Bacteriol 38, 269-272.

Kimura, M. (1980). A simple method for estimating evolutionary rates of base substitutions through comparative studies of nucleotide sequences. J Mol Evol 16, 111-120.

Komagata, K. \& Suzuki, K. (1987). Lipid and cell wall analysis in bacterial systematics. Methods Microbiol 19, 161-207.

Manome, A., Okada, S., Uchimura, T. \& Komagata, K. (1998). The ratio of L-form to D-form of lactic acid as criteria for the identification of lactic acid bacteria. J Gen Appl Microbiol 44, 371-374.

Marmur, J. (1961). A procedure for the isolation of deoxyribonucleic acid from microorganisms. J Mol Evol 3, 208-218.

Nonomura, H. (1983). Lactobacillus yamanashiensis subsp. yamanashiensis and Lactobacillus yamanashiensis subsp. mali sp. and subsp. nov., nom. rev. Int J Syst Bacteriol 33, 406-407.

Okada, S., Hosoi, Y., Takahashi, M. \& Kozaki, M. (1991). A rapid method for the determination of the fermentation types, homo- and hetero-fermentation, of lactic acid bacteria. Bull JFCC 7, 6-10 (in Japanese).

Saitou, N. \& Nei, M. (1987). The neighbor-joining method: a new method for reconstructing phylogenetic trees. Mol Biol Evol 4, 406-425.

Tamaoka, J. \& Komagata, K. (1984). Determination of DNA base composition by reversed-phase-high-performance liquid chromatography. FEMS Microbiol Lett 25, 125-128.

Tanasupawat, S., Okada, S. \& Komagata, K. (1998). Lactic acid bacteria found in fermented fish in Thailand. J Gen Appl Microbiol 44, 193-200.

Thompson, J. D., Gibson, T. J., Plewniak, F., Jeanmougin, F. \& Higgins, D. G. (1997). The CLUSTAL_X Windows interface: flexible strategies for multiple sequence alignment aided by quality analysis tools. Nucleic Acids Res 25, 4876-4882.

Toda, T. (1928). Flagellar staining. Nihon Ijishinpo 283, 113 (in Japanese).

Zhu, H., Qu, F. \& Zhu, L. H. (1993). Isolation of genomic DNAs from plants, fungi, and bacteria using benzyl chloride. Nucleic Acids Res 21, 5279-5280. 